\title{
London 2012 Olympic Games: Challenges Faced by Islamic Olympians Fasting for Ramadan
}

\author{
Razaq Raj \\ Leeds Beckett University, Leeds, UK \\ Tahir Rashid \\ University of Salford, Manchester, UK
}

\begin{abstract}
Fasting is a common practice among many religions in the world. In the ancient religions, fasting was observed as common religious practice associated with many religious festivals. Fasting was also observed in the Judaism and Christianity as part of the religious belief. Therefore, Islam has also prescribed fasting for Muslim in the form of a-month long period of obligatory acts of worship. Ramadan is the ninth month of the Muslim calendar, during which they observed the fasting among daylight hours. The paper has explored significance of Ramadan and impact it had on Muslim athletes during the London 2012 Olympic Games. The Olympic Games were scheduled during the month of Ramadan and the impact of the Olympic Games on Muslim athletes, visitors, and viewers was described, because main Olympic events were scheduled during the breaking of the fast. This paper presents the findings of the primary research undertaken to assess the views and opinions of both the Islamic religion and other religions, concerning the impact of religious festivals on the Olympic Games. The results concluded that most of the people have no idea that there could be an impact of religious festivals on the Olympic Games.
\end{abstract}

Keywords: Ramadan, fasting, Olympic Games, Islamic, Muslim athletes, religion

\section{Introduction}

The Olympic Games in 2012 in London were scheduled from 27th of July to the 12th of August, while the holy month Ramadan was from 20th of July to the 20th of August. The month of Ramadan for Muslims is the fasting month and is the month in which the revelation of the Qur'an was revealed to Prophet Muhammad (peace be up on him). It is the holy month in the Islamic calendar or so-called hijri calendar. This issue can be focused through different perspectives. One could be the Muslim participants, another perspective to look at is Muslim visitors of the Olympic Games, and a third one could be supporters. Ramadan and fasting can have serious influences for all these different groups.

The Islam religion represents about $22 \%$ of the world population, having approximately 1.5 billion adherents. Islam is the second largest religion, with Christianity being the most prominent with an estimated 2.1 billion followers (Retrieved from http://www.adherents.com/Religions_By_Adherents.html). Its adherences are

Razaq Raj, Ph.D., principal lecturer, Leeds Business School, Leeds Beckett University, Leeds, UK.

Tahir Rashid, Ph.D., senior lecturer, Salford Business School, University of Salford, Salford, Manchester, UK.

Correspondence concerning this article should be addressed to Razaq Raj, Leeds Business School, Leeds Beckett University, 520 The Rose Bowl, Portland Gate, Leeds, LS1 3HB, UK. E-mail: r.raj@leedsbeckett.ac.uk. 
called Muslims. They believe in their holy book Qur'an dictated by "Allah" their God, through the angel Gabriel to Prophets from Abraham to Muhammad (Collinson \& Miller, 1985; Brown, 1986).

\section{Background}

\section{Sawn-Fasting During Ramadan}

Ramadan is the 9th month of the Islamic calendar. It is the only month mentioned in the Qur'an. The month of Ramadan is that in which the Qur'an was sent down. It is mentioned in connection with the fasting during Ramadan (Gibb \& Kranmers, 1961). Because of the fact that Ramadan rotates around the seasons, the length of the days differs each year, depending on whether Ramadan falls in winter or in summer time.

To understand the importance and the meaning of that month, there has to take a closer look on the history of Prophet Muhammad's life. Collinson and Miller (1985) stated that at the age of 40, Muhammad thought that there must be a deeper meaning of his life. In the month of Ramadan, Muhammad found the answer. The angel Gabriel inaugurated Muhammad that he is the messenger of Allah.

The night of the revelation of the Qur'an to Muhammad is on the 27th of Ramadan. This night is very important for Muslims and known as the night of the power. Muslims are expected to stay awake in this special night, praying to Allah and reading the holy Qur'an. The whole month of Ramadan and especially Lailat $u l$-Quadr is very important for Muslims to remember that this was the time when Allah was first given the words of the Qur'an to Muhammad (Collinson \& Miller, 1985; Brown, 1986; Ruthven, 1997)

Every Muslim over 12 years and physically fit has to fast during the month of Ramadan; apart from pregnant women, elderly, and those who are sick or travelling. However, they are required to catch up the number of fasting days at a later time (Collinson \& Miller, 1985; Brown, 1986). The last 10 days of Ramadan is the time when Muslims, who can afford it, stay in the mosque for praying, fasting, and meditating. Apart from praying time in the community and the breaking of the fast after sunset, they stay alone. This behavior is known as ihtekaf (a form of worship) (Collinson \& Miller, 1985).

Ramadan in 2012 is taking place from 21st of July to the 19th of August. Because of the fact that the Muslim calendar is not adequate to the Western one, the date of Ramadan differs every year and rotates around the seasons (Retrieved from http://www.islamicinsights.com/entertainment/sports/picking-our-battles-2012olympics-scheduled-during-ramadan.html).

\section{Islamic Festivals}

Festivals have always played an important role in the history of the human being. Eid or $i d$ is the Arabic word for Islamic festivals. They are celebrated by Muslims all over the world. In fact, the Islamic calendar differs from the Western calendar and their festivals rotate through the seasons and are undated to specific days in the Western year. Every festival begins with praying. Most of the Islamic festivals or events are celebrated related to the life of Muhammad and the history of Islam (Brown, 1986).

\section{Eid ul-Fitr-Festival of Breaking the Fast}

Ramadan is the holy month for Muslims. The festival Eid ul-Fitr is the festival of breaking the fast and represents the end of the Lenten season. It is celebrated on the first day of the following month called Sha'ban.

Collinson and Miller (1985) stated that the celebration of Eid ul-Fitr begins in the morning with praying in the mosque. The Imam gives a special sermon in which he reminds the followers to worship Allah and take care for people in need. 
Brown (1986) compared Eid ul-Fitr to the festival of alms-giving. In relation to Collinson and Miller (1985), Muslims give charity to those who are in need. The charity of the fast is known as zakat-ul-fitr. Haneef (2006) described the zakat as a special amount of grain or foodstuff. It can be an equivalent amount of money to cover the cost of one meal.

This day is a joyfully festival. Muslims are dressed up with their best clothes. All family members are invited to join the celebration, children are given gifts, and Muslims congratulate each other. "The festival acts as a renewal of their pledge to the faith and the Muslim community and creates an atmosphere of unity and togetherness" (Brown, 1986, p. 222).

\section{Olympic Games}

The Olympic Games are world-famous sports events taking part every fourth year. Firstly, this chapter gives a general overview of the Olympic Games. The Olympic movement will be described with its main groups and their functions. Later on, the authors examine the Olympic Games 2012 in London with some general information about number of athletes and visitors. Main point of this chapter is the fact that the Olympic Games 2012 are taking place during Ramadan. The authors examine some occurring problems and present some statements of athletes and the Olympic Committee.

\section{Olympic Games 2012 in London}

The official homepage for the Olympic Games gives several relevant numbers and information for the research of this dissertation. London is elected as the host city for the Olympic Games in 2012. The scale of the games shows a huge number of participants and visitors. There will be about 10,500 Olympic athletes and 4,200 Paralympic athletes. About 20,000 press and media and more than 10 million tickets are available. These 10 million tickets are divided into eight million for the Olympic and two million for the Paralympic Games. About 25 Olympic sports and 20 Paralympic sports in either 34 or 21 venues are taking place in 2012. The Olympic Committee expects up to 180,000 spectators every day. Relating to that, the Olympic Games is the focus of the summer 2012 (Olympic, 2010).

J. Gold and M. Gold (2008) stated that there will be over 250,000 volunteers recruited for the Olympic Games 2012 in London. "An estimated 5,000 people participated in the event programme held in various community venues in the five Olympic boroughs" (J. Gold \& M. Gold, 2008, pp. 307-308).

They also mentioned that there will be 3,600 apartments in the Olympic village and 9,000 in the Olympic Park area. The Olympic Games 2012 could be a tourism problem for the host city London. Visitor numbers could reduce for London Olympic Games (China Network Television, 2010).

As mentioned before, the Olympic Games can be defined as hallmark tourist events with its primary function to provide the host community with an opportunity to secure a position of prominence in the tourism market for a short period of time. The expected numbers of visitors for the Games are around 350,000 foreign visitors predicted per day during the Olympics (Retrieved from http://www.hotel-industry.co.uk/ 2010/09/london-olympics-2012-will-arrivals-fall-during-london-olympics-2012/). The European Tour Operators Association (ETOA) suspects that the benefits of the games are an illusion and might be harmful. They state that London had nearly 15 million visitors in 2008, bringing in eight billion. They compare the London Olympic Games with the ones in Beijing and state when they went the same way.

\section{Olympic Games 2012 and Ramadan}

There are several discussions about the Olympic Games taking place during the holy month of Ramadan. 
Many people recommend to this topic and a huge amount of articles have been written. The chairman of the Islamic Human Rights Commission pointed that the Olympic Committee would not schedule the games during the time of Christmas, so why during the time of Ramadan, the holy month for Muslims? He also stated that the organisation shows a lack of sensitivity and awareness (Retrieved from http://www.islamicinsights. com/entertainment/sports/picking-our-battles-2012-olympics-scheduled-during-ramadan.html).

This affects not only the participants but also all people who want to watch the games. It is obvious that they are not willing to travel or watch the games during the time of Ramadan, being a spiritual time for any Muslims in the world. In this opinion, all Muslim athletes will be suffering from that fact and are being discriminated. More than 3,000 athletes come from countries with predominantly Islam religion (Retrieved from http://www.pi-news.net/2010/08/moslems-beleidigt-wegen-olympia-im-ramadan/).

However, the Olympic Committees responded to those articles in mentioning that any date would have been a conflict in respect of all worlds' religions. Therefore, it would not be possible to find any date which fits best. There would always be one or more religion which would feel disabled against the others.

Apart from that several arrangements have been made for Muslim participants, for example, there will be several prayer areas near to the arenas and in the Olympic village as well as the Olympic Committee provides the athletes and their team to have breakfast very early in the morning (Retrieved from http://www.pi-news.net/2010/08/moslems-beleidigt-wegen-olympia-im-ramadan/). One spokeswoman for the London Games stated that some alterations can be made. They will schedule long-distance races at the evening or some other events in the early morning that those athletes who want to fast during that time can have something to eat or drink directly before or after the event. A kind of guideline for the Olympic Games 2012 would be Singapore 2010. The Olympic Committee also decided to schedule the games during the month of Ramadan.

The ultimate decision must be made by the athlete itself. There are as well some Muslim athletes who do not fast during that time but will do so when the Olympic Games are over. All in all, the Olympic Committee wants to stress out that no one has been blocked from the Olympics on the basis of religion (Retrieved from http://www.newstatesman.com/blogs/the-staggers/2010/08/during-ramadan-fast-muslim).

The International Olympic Committee (IOC) gave the city a binding window for the games. This window was from July 15 to August 31, which would be one week before Ramadan. London decided to schedule the games from July 27 to August 12, which is in the month of Ramadan. An IOC spokeswoman said that it is up to the athletes that how to deal with religious clashes; the games just bring every religion and creed together (Retrieved from http://www.gamesbids.com/eng/index.php?news=1160922510). Someone excused that by saying that they didn't know about that issue. They had to consider a lot of different things as well as the summer holidays. According to that, the Olympic Committee is working closely with the Muslim Council of Great Britain in order to accommodate Ramadan during the Games.

A member of the IOC gave a statement about fasting and sports in April 2009. He advised all athletes who want to fast during the games to get professional advice in order to develop a personal strategy. These athletes have to be sure that fasting is of no risk to their health. He reminded all event managers to be aware of any implications as well as to adapt to the needs of these athletes, support staff, visitors, and officials whenever possible (Retrieved from http://multimedia.olympic.org/pdf/en_report_1429.pdf).

In relation to Muslim participants and any affect to their performance during Ramadan, different statements are listed below. There are either positive or negative ones: 
- A Pakistan cricketer says that it is a sin for Muslims not to fast during the month of Ramadan. According to him, cricket should not be played during Ramadan;

- A South African cricketer sees playing during Ramadan as an advantage. People get amazed when he told them that he has learned so much in his games while he had been fasting. It does affect the matches and trainings, positively mostly, Alhamdulillah;

- A professional footballer currently playing for Manchester is also a devout Muslim. He stresses out that fasting does not affect him physically, it makes him stronger. He believes that this is because of his strong belief in Allah (Retrieved from http://www.newstatesman.com/blogs/the-staggers/2010/08/during-ramadanfast-muslim).

\section{Methodology}

The literature research comprised of texts from books, journals (electronic and hard copy), newspaper, periodicals, and internet articles. Data came from the field of events, tourism, the Muslim religion, and the Olympic Games. A primary research was carried out to gain in-depth information of London 2012 Olympic Games. It was decided that the use of questionnaires would be a more appropriate method of obtaining the information required. A fully structured questionnaire, according to Jankowicz (2005), was used and sent to several National Olympic Committees (NOCs) and IOCs in Europe, America, and the Middle East and Asia.

This paper presents the findings of the primary research undertaken to assess the views and opinions of both the Islamic religion and other religions, concerning the impact of religious festivals on the Olympic Games. The chosen sample includes a 155 total questionnaires send out to different groups of people, 75 of which were sent to IOC, NOC, Islamic Committees, and training schools and 80 to students.

\section{Findings and Discussion}

All key findings which were gathered from the primary research undertaken will be presented in figures, tables, and diagrams. Firstly, the answers to relevant questions will be shown separately to give the reader a general overview of the research questions. In the next step, the authors combine and evaluate several questions and answers in order to get a better understanding of the different opinions and views.

Figure 1 shows the fragmentation of gender from all participants taking part in the online questionnaire. The percentage of female (47\%) and male (53\%) participants clearly reflects a balance between the two sexes. Statics from the United Nations (2009) show that the number of males in the world population is a little bit larger that the number of the female population. This identifies a balance between the sexes. According to studies from the United Nations in 2009, the present research result can be seen as a representative sample.

The second question of the questionnaire was about religion. The pie chart below shows as well a good balance between the Christian religion and the Islam religion. Only $7 \%$ of the participants have a different religion. The finding of this question identifies a good representation of the worlds' largest religions. Christianity is the largest religion with $50 \%$ and Islam is the second largest religion with $43 \%$.

For the purpose of the present research, a percentage of $43 \%$ for the Islam religion presented in Figure 2 is a very good point of origin. The research gains valuable results, when the views and opinions of the two largest religions in the world (Christianity and Islam) will be combined later part of the paper.

Figure 3 presents the percentage of all countries' participants who have participated in the Olympic Games. The majority of participants come from Europe including Germany, United Kingdom, and France. The part 
"others" includes Malaysia, China, Iraq, and Pakistan. The number of participants coming from these countries would have been too little to list them separately in the Figure 3.

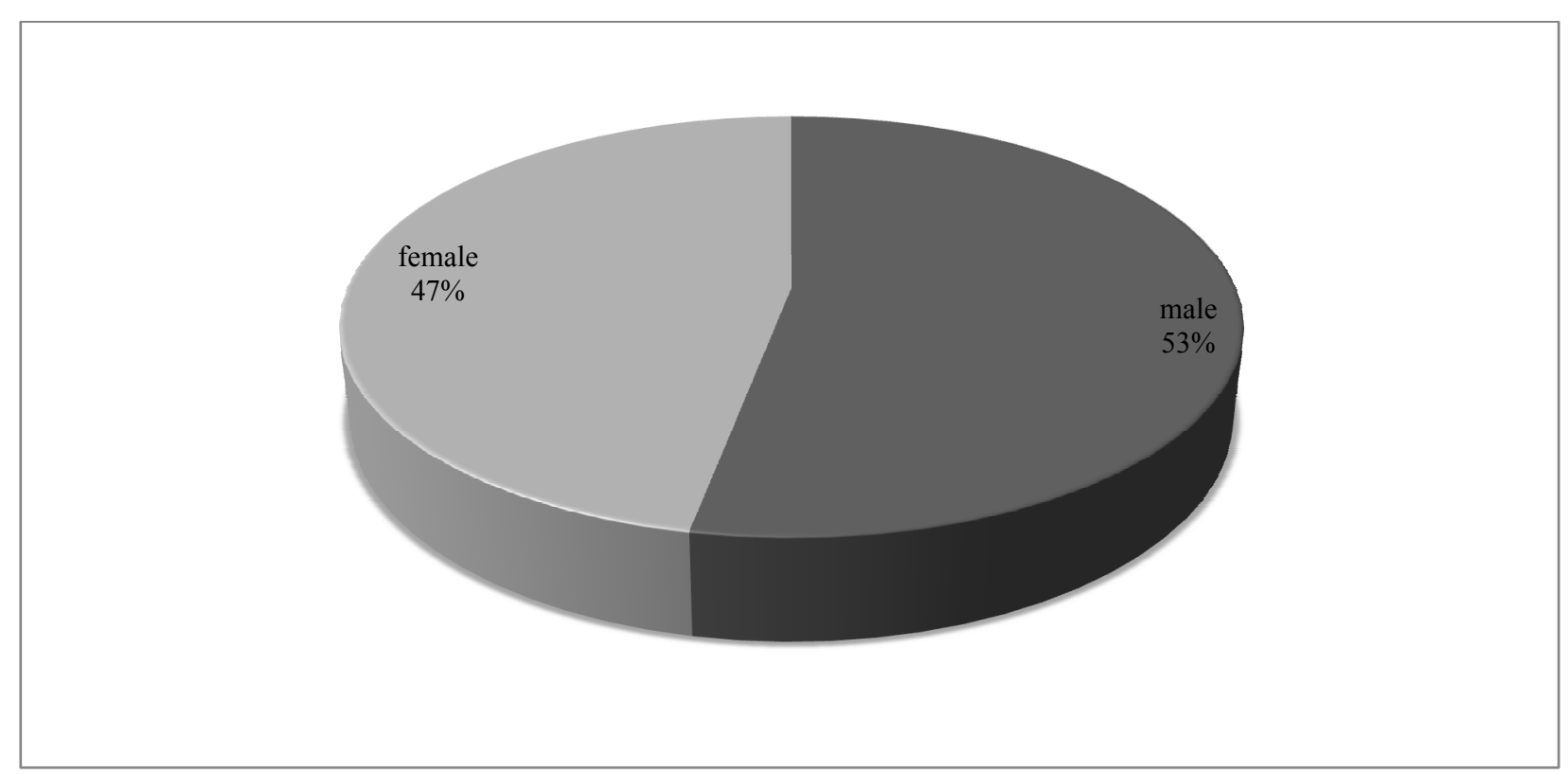

Figure 1. Gender.

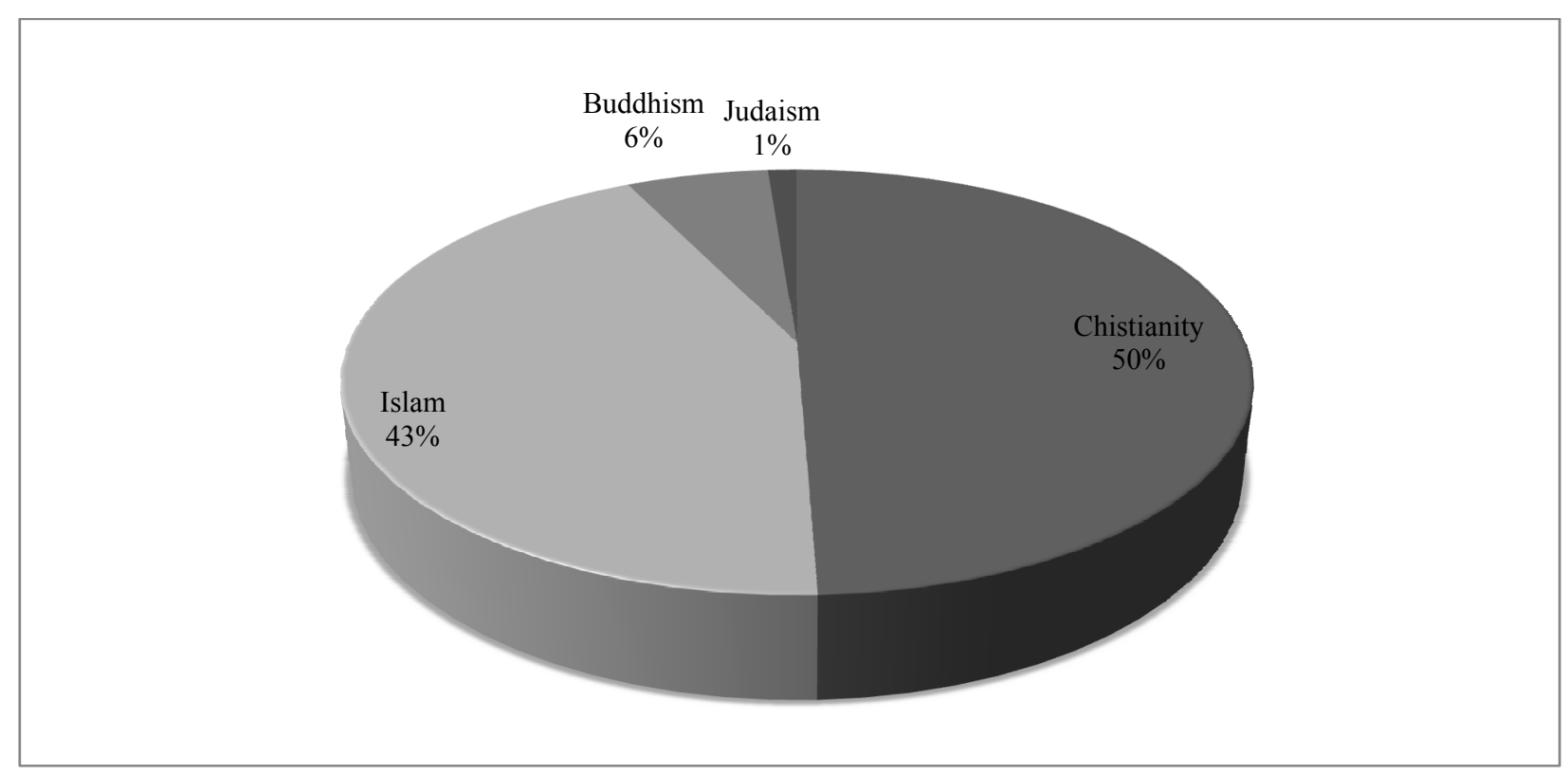

Figure 2. Religion.

An absolutely clear answer was achieved with the question of whether the participants ever heard of Ramadan or not. There were only $4 \%$ of the participants who had not heard about Ramadan. This provides a good result for the authors to have only a very little number of participants taking part in this research with no knowledge about that topic (Figure 4).

Out of the $96 \%$ saying they have heard about Ramadan, $40 \%$ of the participants gave a short definition of it. Most of these definitions included the abstinence from drinking, eating, alcohol, tobacco, and sex, during the 
daytime (Collinson \& Miller, 1985; Brown, 1986). The definitions of the participants also stated that Ramadan is a holy month in the Islamic calendar and one of the five pillars of Islam.

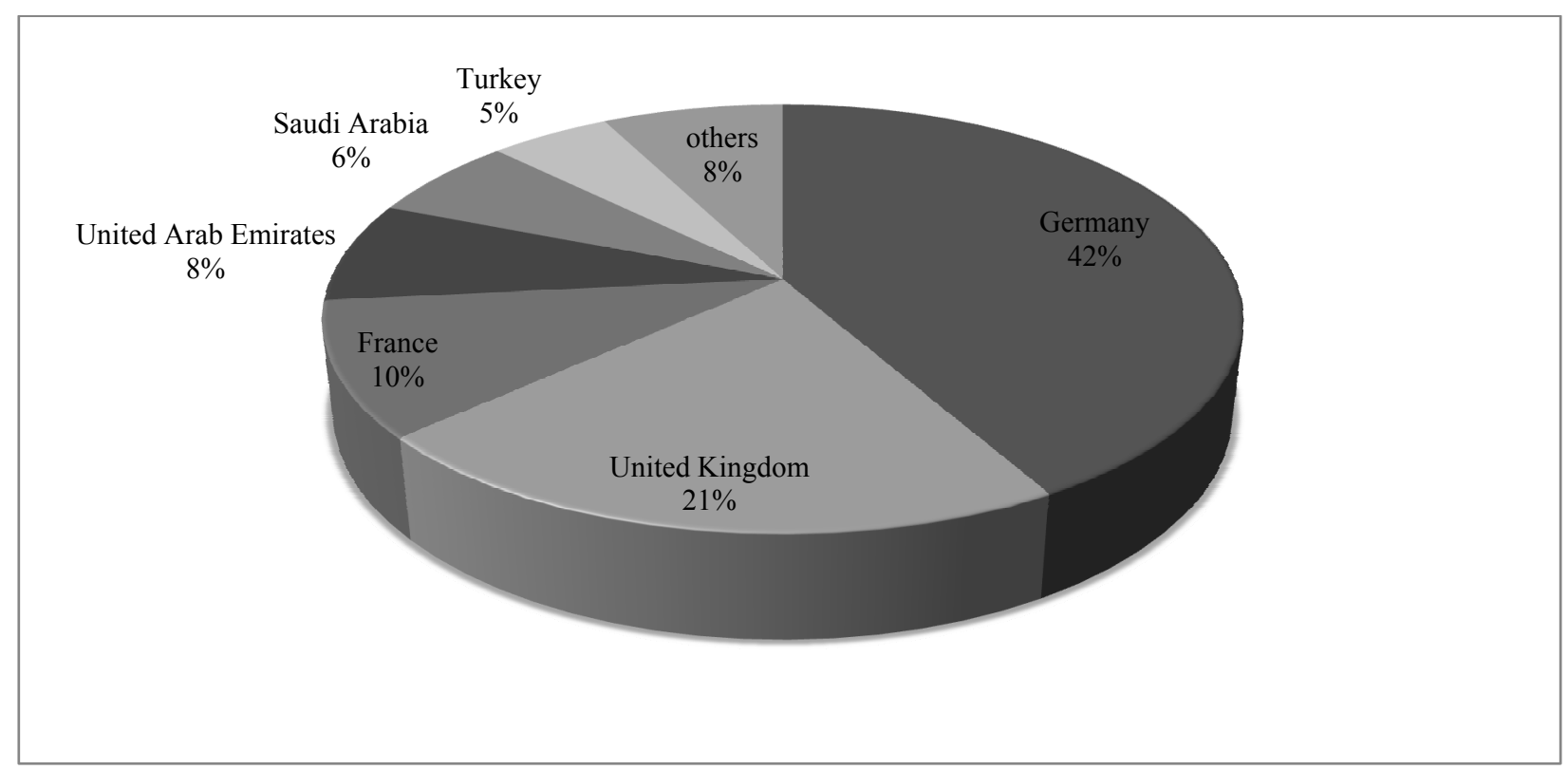

Figure 3. Country.

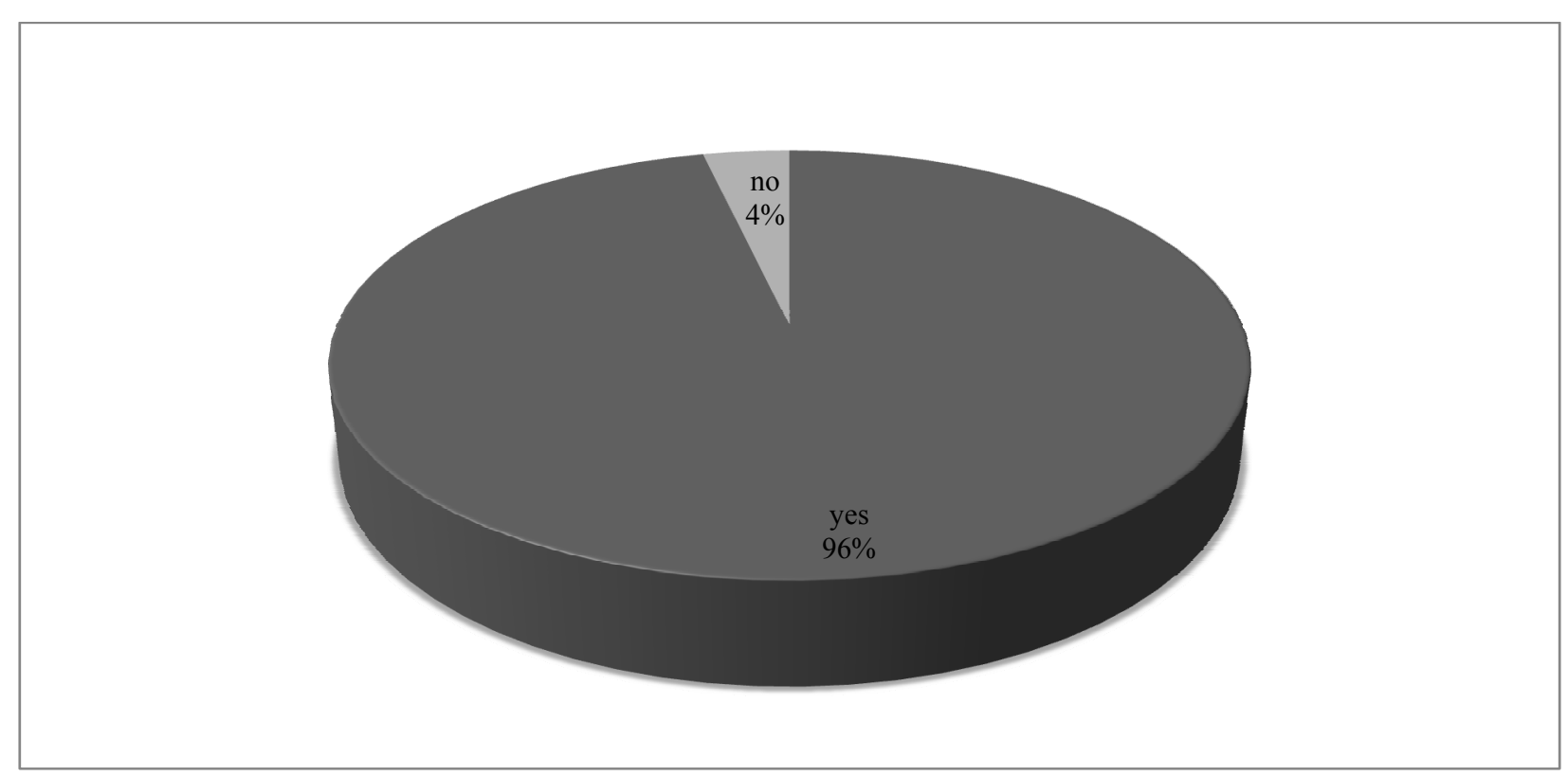

Figure 4. Have you heard about Ramadan?

Figure 5 shows a relatively high percentage (59\%) of participants having not known that the Olympic Games 2012 are taking place during Ramadan. This outlines that more than a half of the participants do not know that there might be a clash or impact between the Muslim religion and the Olympic Games 2012 in London. This fact underlines the importance and necessity of presenting and analysing this kind of issue.

The results combined the answers given from Muslims with the ones given from participants of other religions. From the results, it does indicate that Muslims did not know that the Olympic Games 2012 in London 
was taking place during Ramadan. Figure 6 outlines that about one-third of the Muslims do not know about this matter of fact that Olympic Games was taking place during the holy month of Ramadan. In relation to the other religions, more than a half of the participants $(60 \%)$ do know neither.

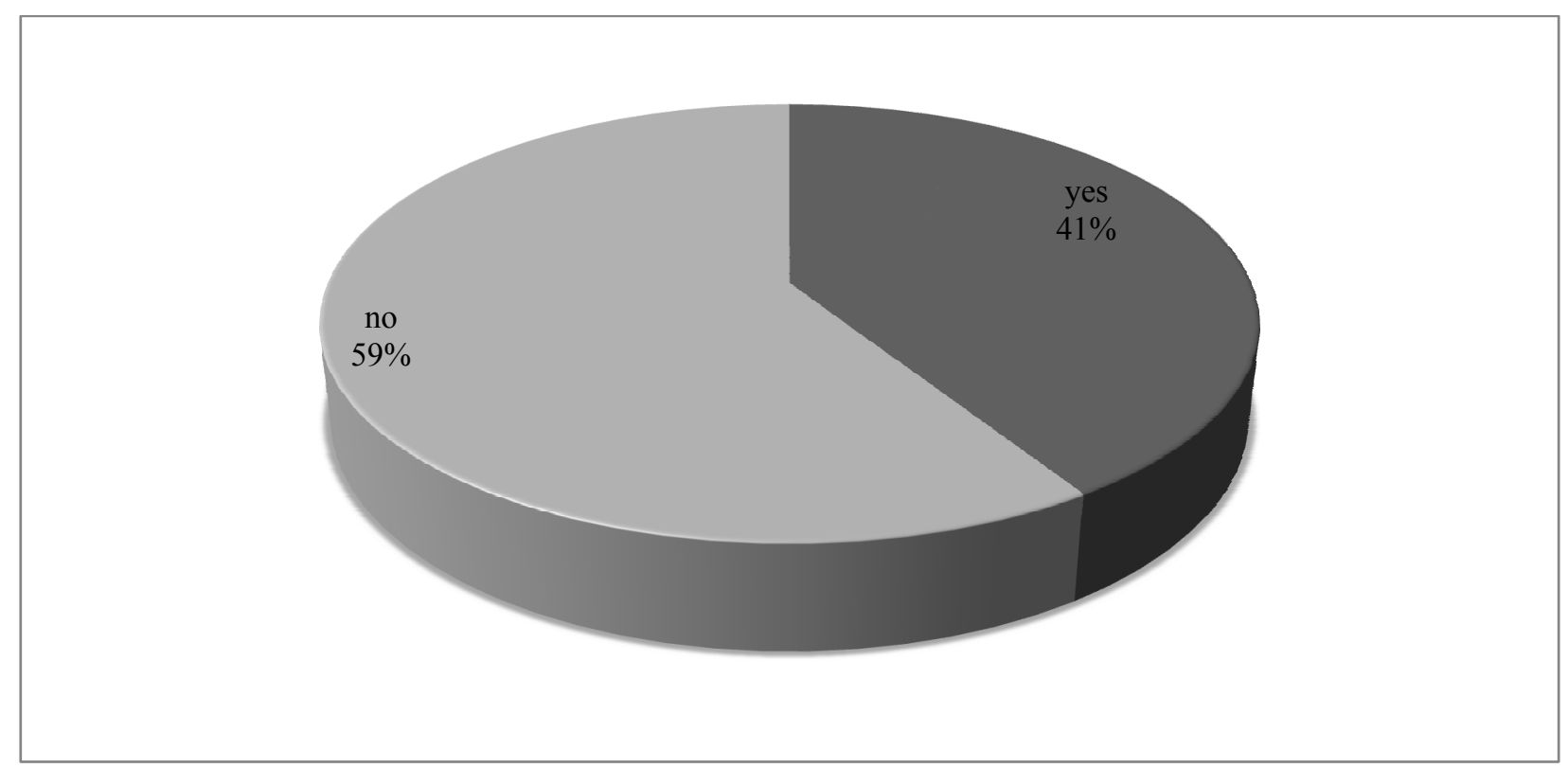

Figure 5. Do you know that the Olympic Games 2012 in London are taking place during Ramadan?

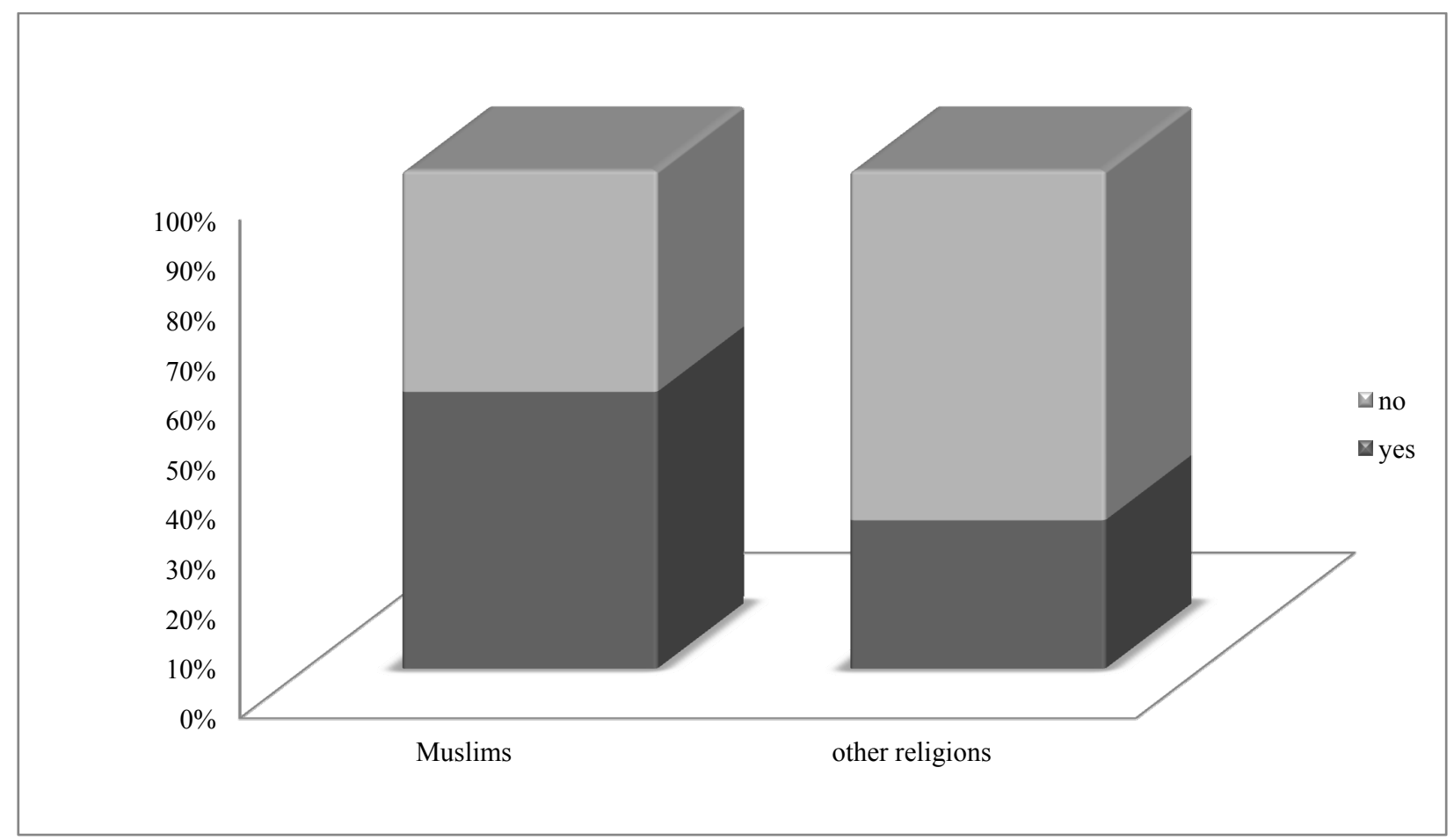

Figure 6. Do you know that the Olympic Games 2012 are taking place during Ramadan?

The next four Figure 7, 8, 9, and 10 show the answers. This question was divided into nine different small questions in which the participants of the research study were asked to tick the appropriate boxes saying 
whether "yes", "no", or "probably".

Figure 7 shows that for both questions (are you interested in the Olympic Games/do you watch the Olympic Games on TV), more than half of the participants are interested in the Olympic Games and watch the Olympic Games on TV. There are just a few participants saying that they are not interested in the Olympic Games and won't watch the Games on TV.

The majority (68\%) of participants are interested in the Olympic Games. Because of the majority watching the Olympic Games (64\%), it backs up the validity of the chosen sample.

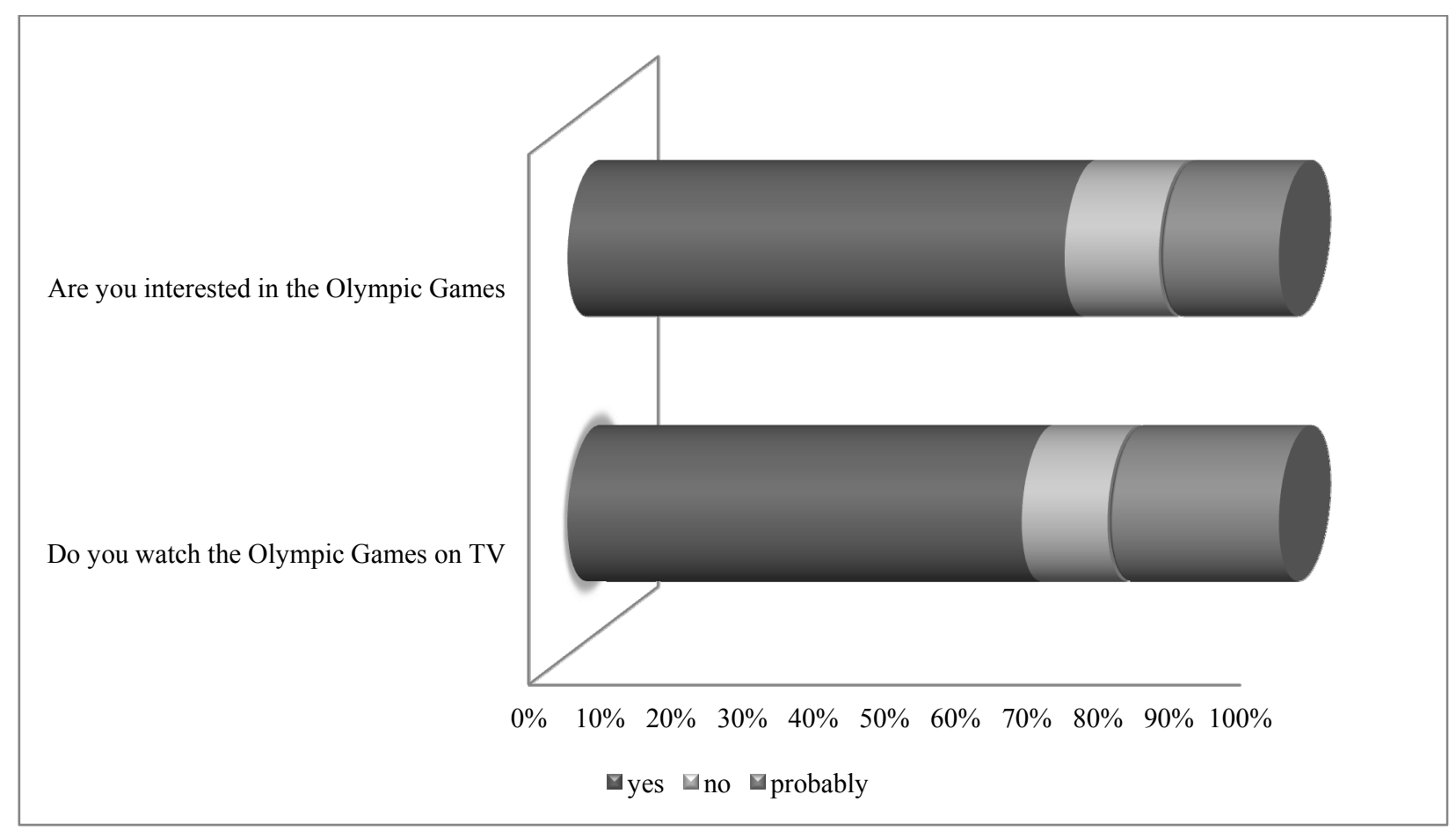

Figure 7. Part one of question.

As stated in the methodology, it was not possible to contact all athletes of the Olympic Games. This is underlined in the below shown in Figure 8. There are only a number of 14 people taking part in the Olympic Games (17\% of the participants) and a number of three (3.6\% of the participants) saying that they might probably take part in the Olympic Games.

The number of people travelling to London to watch the Olympic Games is 24 (30\% of the participants) and there is a number of seven ( $8.8 \%$ of the participants) saying that they will probably travel to London to watch the Games.

Compared to the number of athletes, this relates to a number of seven people ( $8.8 \%$ of the participants) visiting London to watch the Olympic Games and a number of four people (5\% of the participants) who will probably travel to London to watch the Olympic Games.

Figure 9 shows that $65 \%$ of the participants taking part in this research do not think that the Olympic Games should be scheduled during religious festivals. This outlines the importance of this topic and identifies that the organizers of the Olympic Games should be aware of scheduling events during religious festivals. In relation to that, chairman of the Human Rights Commission mentioned the issue as a lack of awareness and sensitivity. 


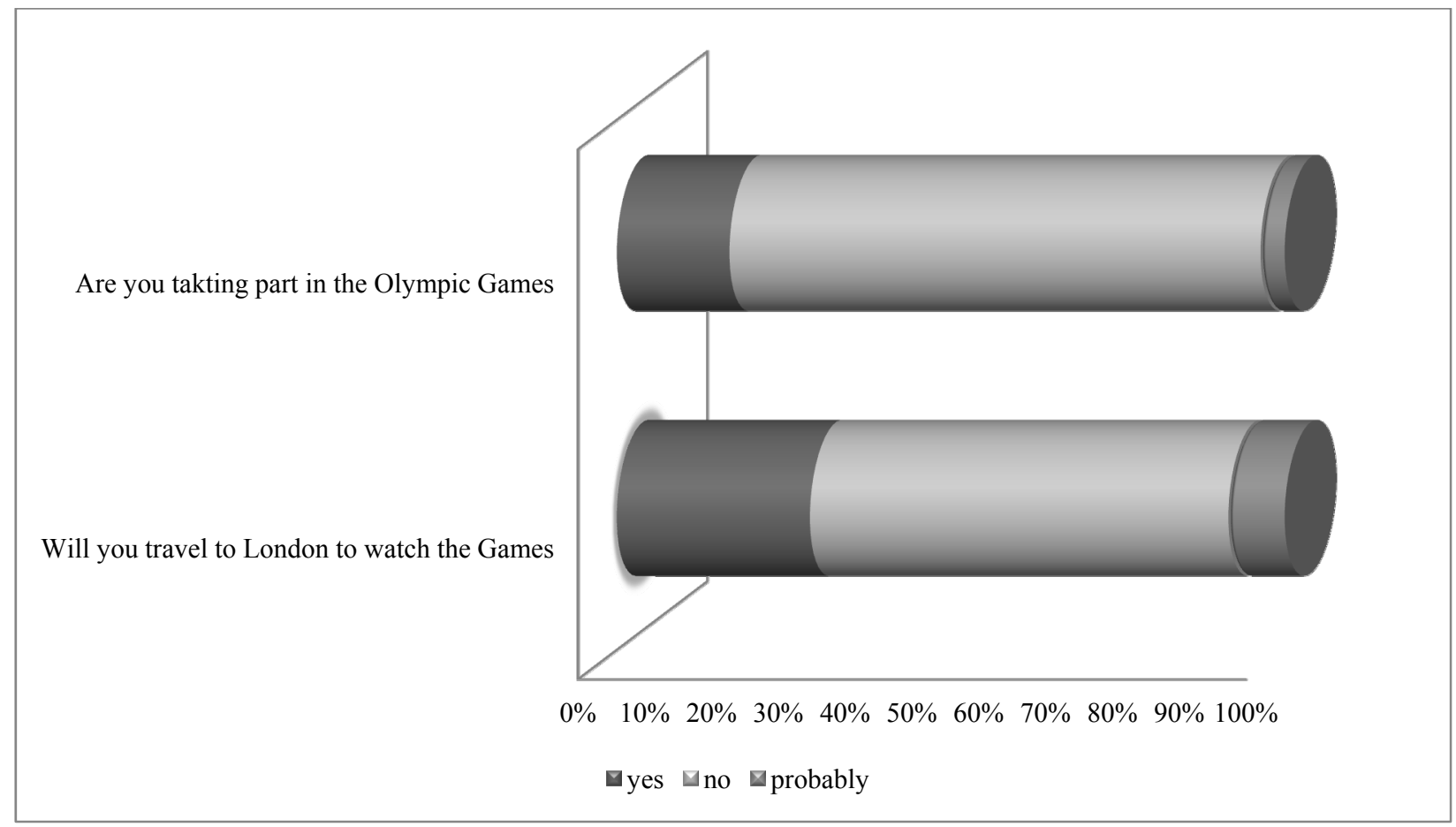

Figure 8. Part two of question.

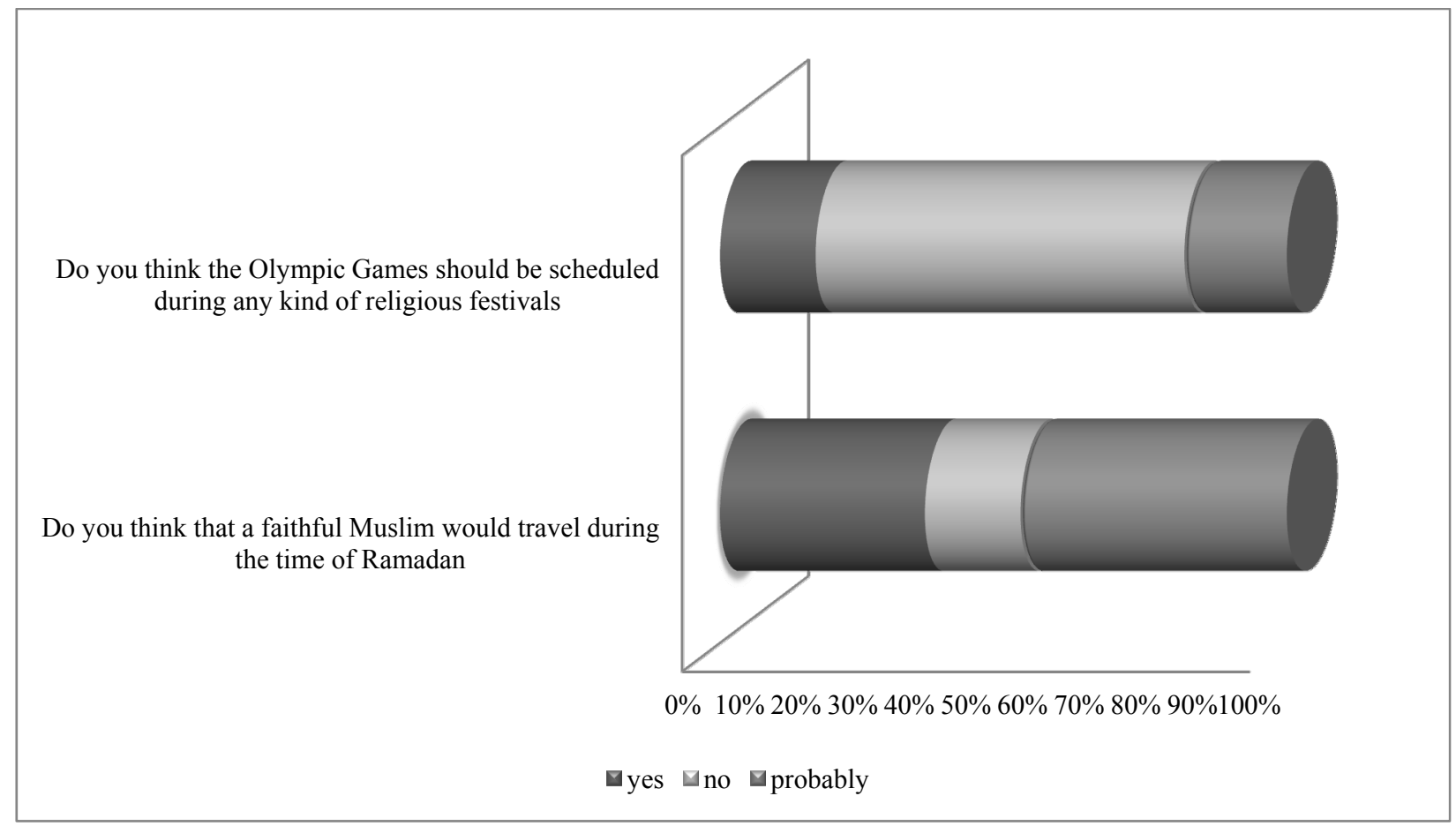

Figure 9. Part three of question.

Scheduling the Olympic Games during religious festivals, in this case-Ramadan, will affect not only Muslim athletes but also people who want to watch the Games. They are less likely to travel during that time of the year, because it is a spiritual and holy time for Muslims. Surprisingly $36 \%$ of the participants are saying that 
a faithful Muslim would travel during the time of Ramadan and $47 \%$ are saying that they probably do so. There are only $17 \%$ saying that a faithful Muslim will not travel during the time of Ramadan.

The research combined the answers given from Muslims with the answers of people from other religions. The results shows that $50 \%$ of Muslims would travel during Ramadan and 33\% are saying that they won't. Twenty-six percent of people with other religions are saying that Muslims will travel and 57\% are saying that they will not. As a conclusion, one can say that non-Muslims rather say that a faithful Muslim will not travel during Ramadan than Muslims do. For this reason, it does not support the above mentioned statement.

Figure 10 clearly identifies that the majority ( $82 \%$ ) of the participants believe that it is a major challenge for Muslim participants to take part in the Olympic Games during the time of Ramadan. Only $10 \%$ disagreed with the majority and $8 \%$ said that there is probably a major challenge for them.

Even though there is a mixed opinion, there is a majority of $46 \%$ saying that it will have a negative impact on Muslim athletes participating in the Olympic Games during Ramadan. One-third of the participants clearly answered that question with no and a percentage of $24 \%$ answered with probably.

To gain a better understanding whether there is any difference between opinions of athletes and opinions of non-athletes, the authors compared them shown in Figure 11.

Figure 11 shows the different opinions of athletes and non-athletes. The majority say that there is a negative impact on Muslim athletes, coming from non-athletes. This outlines that athletes themselves might probably know how to deal with this kind of issue or do not see any problem at all.

The participants were given the chance to make comments to the parts asked in question. A number of six people used that chance and gave some comments which are listed below.

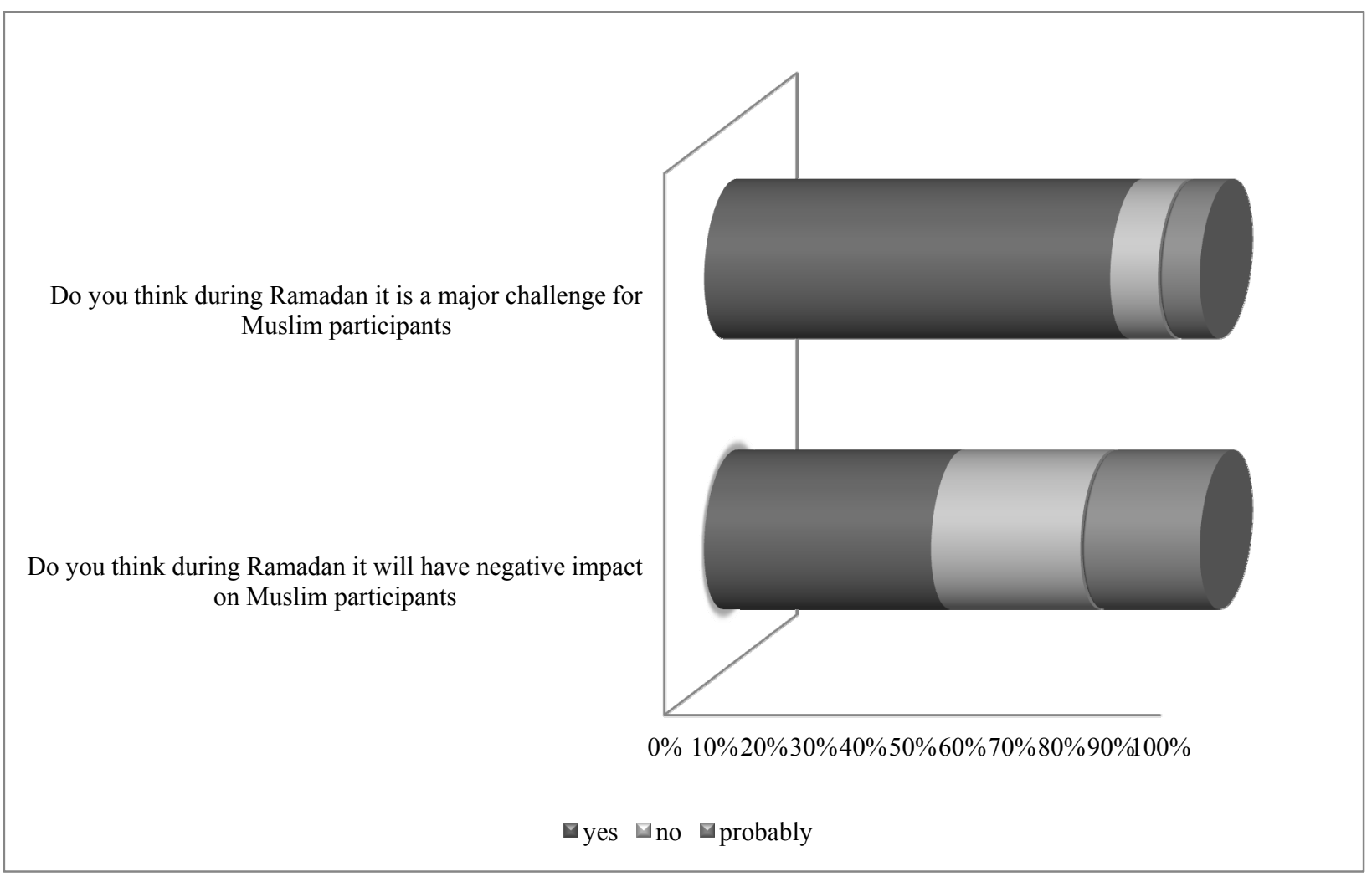

Figure 10. Part four of question. 


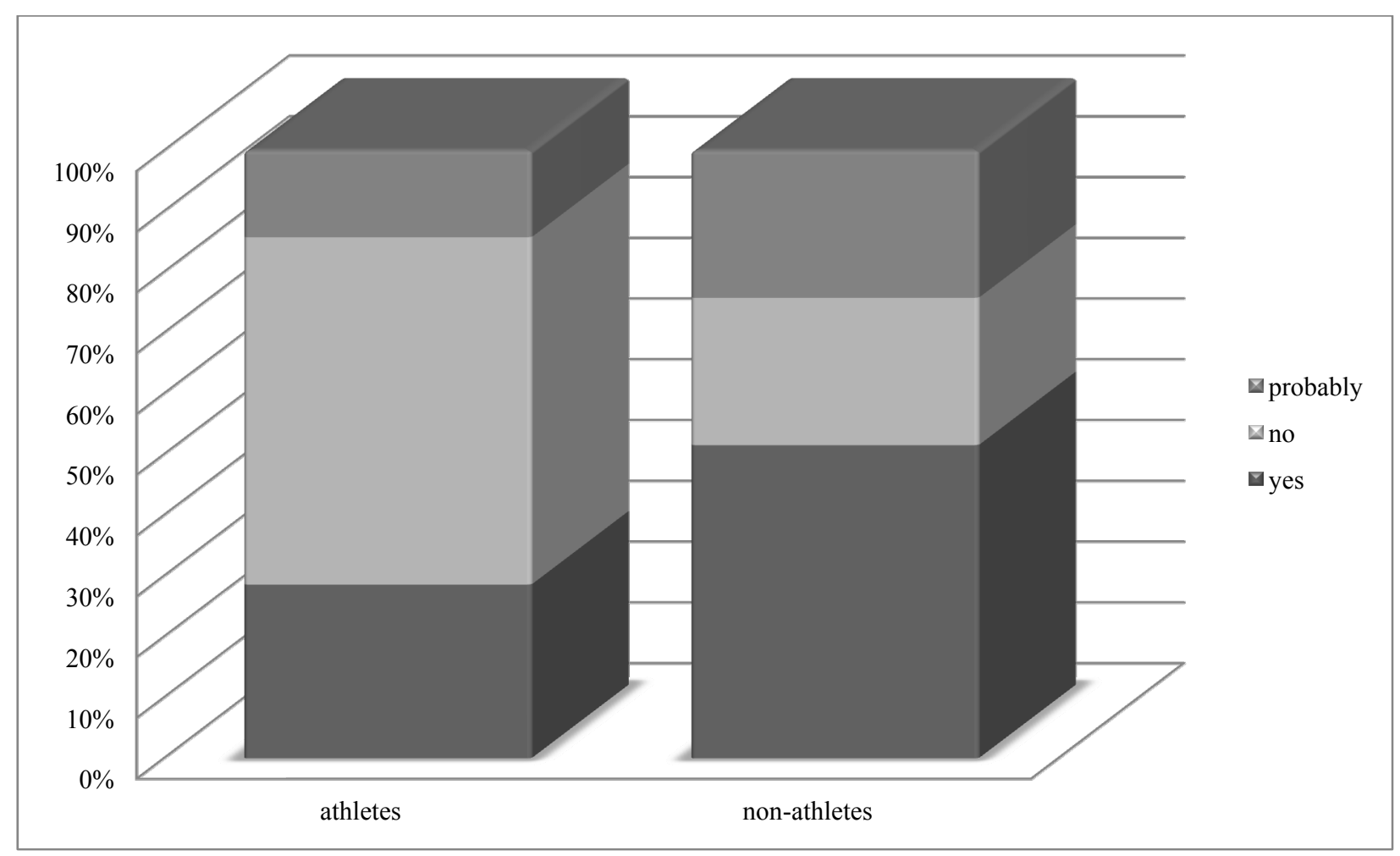

Figure 11. Do you think during Ramadan it will have negative impact on Muslim participants?

If considering all religions in the world, any selected date would be a conflict for someone. It would be almost impossible to schedule events, so they avoided any link to a religious day. This would take out Friday, Saturday, and Sunday to start with.

Figure 12 deals with the opinions and thoughts of the participants about how believers would react if the Olympic Games (winter games) would be scheduled during religious seasons. Because of the quantity and distinction of the answers, the authors summarized them into nine different headings in the following.

As outlined in Figure 12, 21\% of the participants have the opinion that there will be a conflict, if the Olympic Games are scheduled during religious festivals; $15 \%$ of the participants are saying that believers do not have any problem, if the Olympic Games are schedule during any religious seasons; another $15 \%$ of the participants are saying that scheduling the Olympic Games during religious seasons is unfair and shows a lack of awareness of any other religion; $14 \%$ of the participants mention that believers would protest against it and would work together with media to make it to a public issue; unfortunately, there are $13 \%$ saying that they do not have any idea how believers would react, if the Olympic Games are scheduled during religious seasons; additionally, $8 \%$ of the participants believe that if the Olympic Games are scheduled during any religious seasons, athletes might refuse from taking part in the Olympic Games, they also say that the number of visitors might decrease, if this will become true, any host city for the Olympic Games will suffer from that issue; a small number of $6 \%$ have the opinion that athletes have to cope with that matter of fact and they believe that it is their decision how they deal with it; $4 \%$ of the participants mention that believers would like to have the date of the Olympic Games changed, because of this fact; and another $4 \%$ believe that it would be a problem for Christians, if the Olympic Games are scheduled during Christmas or Easter. 


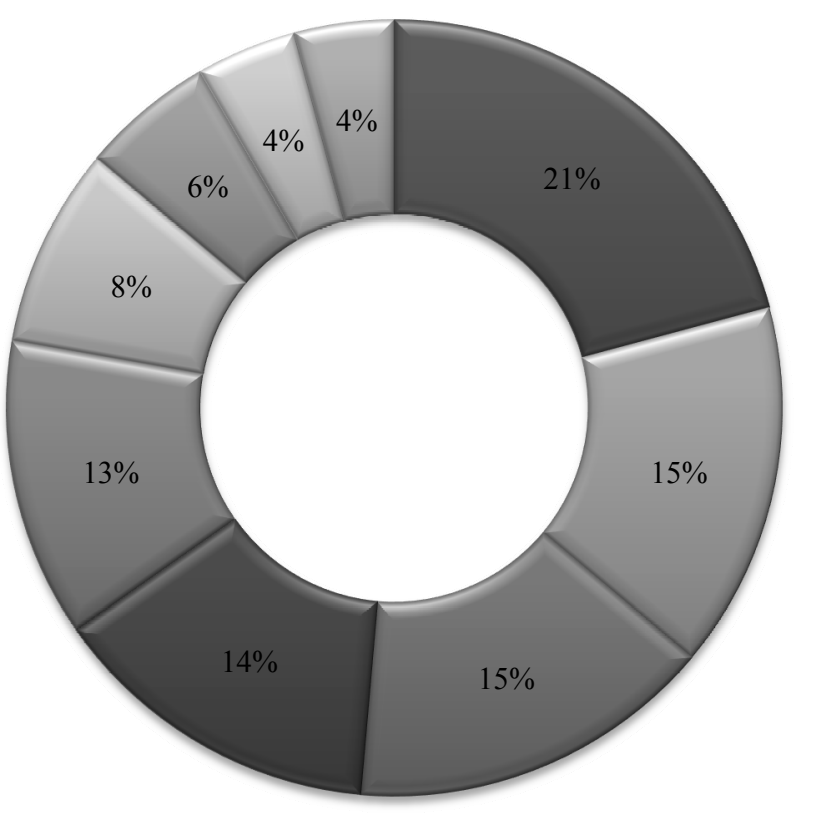

घthere will be a confilct

$\square$ there is no problem

$\square$ it is unfair

$\nabla$ they will protest against it

$\square$ no idea

$\square$ refuse participants and visitors

$\square$ athletes have to cope with that

$\square$ they would like to have the date changed

$\square$ Christians would have a problem if it is during Christmas or Easter

Figure 12. How do you think believers would react if the Olympic Games would be scheduled during religious season?

As highlighted in Figure 13, more than two-thirds of the participants have the opinion that it is important to find a compromise for Muslim participants to take part at the Olympic Games and practice their faith. This again outlines the importance of the present research. There is a high interest in that and the participants want to have a compromise for Muslim athletes.

The majority (49\%) of the participants answered the question-whether the date of the Olympic Games should be changed with yes. A small percentage (39\%) of the participants answered that question with no and there are $12 \%$ saying that they do not care.

Spokeswomen for the London Olympic Games, some long-distance races, are scheduled at the evening as well as some other events are scheduled in the early morning. Figure 14 illustrates that the majority (53\%) of the participants taking part in the research have exactly the same opinion. Another possibility of how to deal with that issue mentioned by $21 \%$ of the participants is that athletes should break up their fast and catch it up later. There are some Muslim athletes who do not fast during that time but will do so when the Olympic Games are over.

In contract to that, a Pakistan cricketer stated that it is a sin, if Muslims do not fast during the holy month of Ramadan.

Apart from that, $21 \%$ of the participants have the opinion that there is no compromise but changing the date of the Olympic Games. This was also outlined where $49 \%$ of the participants say that the date of the Olympic Games should be changed.

The other possibility stated by $5 \%$ of the participants is that they should schedule some games during the night time. This of course would be a disadvantage for visitors and the media. 


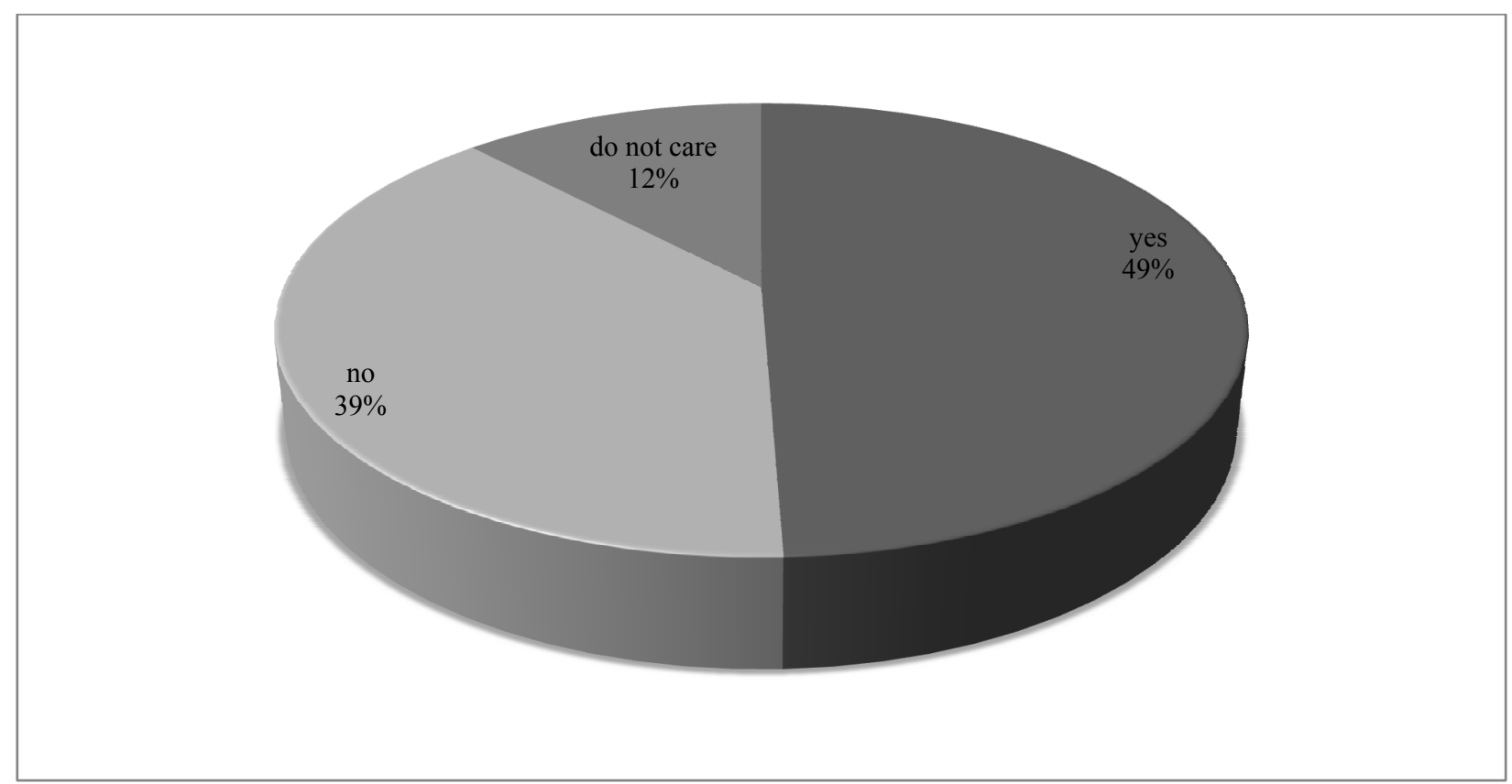

Figure 13. Do you think the date of the Olympic Games should be changed because of the fact that they are taking place during Ramadan?

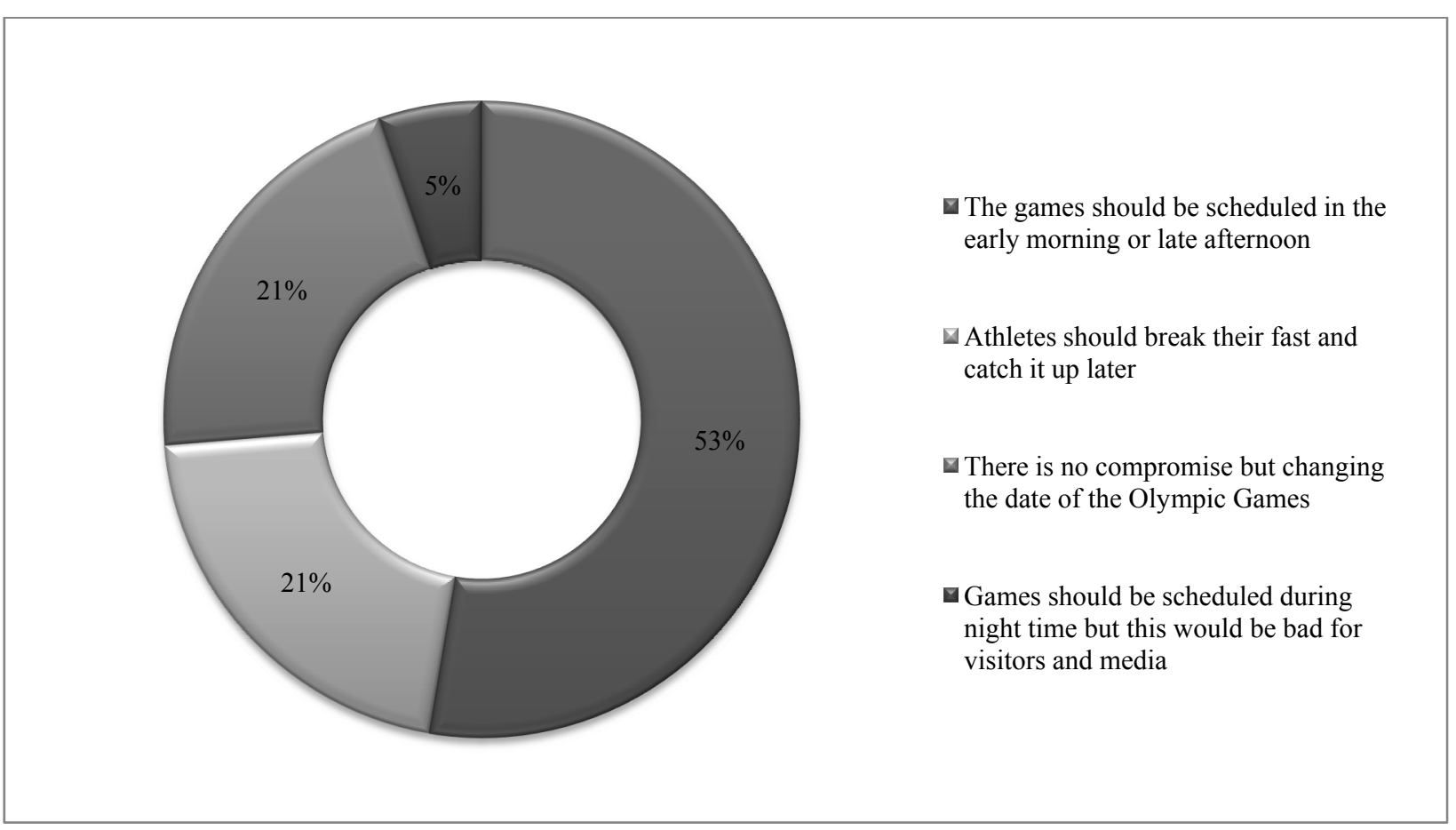

Figure 14. Examples for a compromise.

\section{Conclusions}

The presented findings show that there are a lot of people who do not know that the Olympic Games 2012 in London was taking placing during Ramadan. This matter of fact shows that most of the people have no idea that there could be an impact of religious festivals on the Olympic Games. The majority of the participants do 
not think that the Olympic Games should be scheduled during any kind of religious festivals or seasons. This research has outlined evidence that the number of Muslim athletes or Muslim spectators would decrease, but it outlined that scheduling the Olympic Games or any other world-famous event during religious festivals shows a lack of awareness and sensitivity for any religion. The research presents that the opinions of the participants, whether the date of the Olympic Games should be changed or not, are divided. Apart from that, the majority of the participants believe that it is absolutely essential to find a compromise for Muslim athletes to participate in the Olympic Games and practice their faith.

\section{References}

Adherents. (2007). Major religions of the world. Ranked by number of adherents. Retrieved from http://www.adherents.com/Religions_By_Adherents.html

Brown, A. (1986). Festivals in world religions. London: Longman.

China Network Television. (2010). Visitor numbers could reduce for London Olympic Games. Retrieved from http://english.cntv.cn/program/newsupdate/20101002/100675.shtml

Collinson, C., \& Miller, C. (1985). Celebrations. Festivals in a multi-faith community. London: Hodder \& Stoughton.

Gamesbids. (2010). London 2012 games to be held during Ramadan. Retrieved from http://www.gamesbids.com/eng/index.php?news=1160922510

Gibb, H., \& Kranmers, J. (1961). Shorter encyclopedia of Islam. Leiden: E. J. Brill.

Gold, J., \& Gold, M. (2008). Olympic cities. City agendas, planning, and the world's games 1896-2012. New York: Routledge.

Haneef, S. (2006). What everyone should know about Islam and Muslims? New Delhi: Islamic Book Service.

Hotel Industry. (2010). "Toxic" Olympics effect may hit UK visitor numbers, warns tourist body. Retrieved from $\mathrm{http} / /$ www.hotel-industry.co.uk/2010/09/london-olympics-2012-will-arrivals-fall-during-london-olympics-2012/

Islamic Insights. (2010). Picking our battles: 2012 Olympics scheduled during Ramadan. Retrieved from http://www.islamicinsights.com/entertainment/sports/picking-our-battles-2012-olympics-scheduled-during-ramadan.html

Jankowicz, A. (2005). Business research projects (4th ed.). London: Thompson Learning.

Multimedia Olympic. (2009). Fasting and sports. Retrieved from http://multimedia.olympic.org/pdf/en_report_1429.pdf

Newstatesman. (2010). Is Ramadan a threat to Muslim success at London 2012? Retrieved from http://www.newstatesman.com/blogs/the-staggers/2010/08/during-ramadan-fast-muslim

Olympic. (2010). The organization. Retrieved from http://www.olympic.org/en/content/The-IOC/The-IOC-Institution1/?Tab=1

Pi-news. (2010). Moslems beleidigt wegen Olympia im Ramadan. Retrieved from http://www.pi-news.net/2010/08/moslems-beleidigt-wegen-olympia-im-ramadan/

Ruthven, M. (1997). Islam. A very short introduction. New York: Oxford University Press Inc..

United Nations. (2009). Population division. The 2008 revision. World population prospect. Retrieved from http://www.un.org/esa/population/publications/wpp2008/wpp2008_highlights.pdf html 